\title{
Correlation of phosphorus level with macro- and microelements in the bristles of Landrace pigs
}

\author{
Olga Zaiko ${ }^{1}$, Andrey Nazarenko, ${ }^{2,}$, Marya Strizhkova $^{1}$, Aleksandr Zheltikov ${ }^{2}$, and Tatyana \\ Konovalova ${ }^{2}$ \\ ${ }^{1}$ Novosibirsk State Agrarian University, Faculty of Veterinary Medicine, 630039 Dobrolyubova St \\ 160, Novosibirsk, Russia \\ ${ }^{2}$ Novosibirsk State Agrarian University, Биолого-технологический факультет, 630039 \\ Dobrolyubova St 160, Novosibirsk, Russia
}

\begin{abstract}
The presented results expand the understanding of the normal chemical composition of the body. The study was carried out on the basis of a pig-breeding farm in the Altai Territory in 2016-2020 on clinically healthy 6-month-old pigs of the Landrace breed. Chemical analysis of pig bristles was performed by inductively coupled plasma atomic emission spectrometry. The data were processed using Statistica 8 software (StatSoft Inc., USA). A study of the correlations between phosphorus in bristles and other macro-, microelements, as well as chemical elements associated with phosphorus, has been carried out. Only positive connections of different strengths have been established between phosphorus and elements involved in the formation of bone tissue (calcium, magnesium, manganese), copper, iron and strontium. There are two groups of direct interactions of different strengths between the chemical elements associated with phosphorus. Explained supposedly the essence of the connections, which is consistent in the bristle, as the final site of exchange, with organs and tissues of mammals.
\end{abstract}

\section{Introduction}

In the Russian Federation, since 2005, there has been an increase in the production of pig products. For 2020, an internal market for its own products has actually been formed, and pig farming, as an industry, is practically self-sufficient, one of the most technologically advanced in the state and investment attractive $[1,2]$. The threshold value of the economic affordability of pork in accordance with the Food Security Doctrine of Russia should be $100 \%$, in fact, at the end of the last decade it was $150.0 \%$ with a decrease in imports by $75.0 \%$ and an increase in livestock by $58.8 \%$. The existing production volumes of these products fully satisfy the needs of the population, even exceeding the rational nutritional standards [3].

\footnotetext{
*Corresponding author: andrey2221100@mail.ru
} 
Animals of the Landrace breed are distinguished by high maturity and payment for feed, they are sensitive to a number of factors, but they produce meat with a low level of fat, which is competitively beneficial in the light of most other domestic breeds [4]. With regard to animal productivity, there are critical points that affect it, namely genetic potential, feeding, health and veterinary well-being. The listed factors act in combination, and animals with a genetic advantage do not realize it without an appropriate full-fledged diet [5].

Macro- and microelements that cause growth, development of reproduction of human and animal health [6]. Number of different diseases, for example, autoimmune, neurodegenerative, oncological, metabolic diseases, are associated with an excess, deficiency or imbalance of chemical elements in the mammalian body, and the damage to public health caused by these causes in the world is highly underestimated [7]. In this regard, there is an urgent need to study the mineral status, including of farm animals, the ratio between its components and their relationships, which is relevant in the context of the intake of chemical elements into the human body, as the final link in the food chain, since more than $90 \%$ exposure associated with food of animal origin [8-11].

Assessing mineral status, namely the choice of biological substrate, can be challenging. Traditionally, blood is used for this. But in this case, many factors affect the concentration of chemical elements, and the specified matrix reflects the trace element status based on a limited, often short, period of time. An example of this is the diagnosis of iron deficiency in humans, when the value of serum iron can be reduced, within normal limits and even increased, which depends on the intake of medications containing iron the day before, a meat diet, transfusion [12].

Increasingly, nails, hair, hoof horn, teeth are used as a biological substrate for assessing the level of chemical elements in humans and animals and for biomonitoring. structures that can be archives of concentrations of macro- and microelements [13-20]. As for the derivatives of the skin, the ability to keratinize preserves the chemical elements in keratin, thereby isolating them from the metabolic processes taking place in the body at the moment. Accordingly, the study of these structures can retrospectively reflect the mineral status of the object over an extended period [21,22].

Hair or bristles are very convenient for research, since their samples are easy to take, there is no injury, no equipment is needed for transportation and storage, information value does not disappear for an unlimited time [23]. Based on the study of animal hair samples, there is a method for diagnosing chronic microelementosis of ungulates [24].

In our opinion, pigs are a particularly convenient model, their hairline consists mainly of guard hairs, which have a relatively slow growth rate, which by six months allows obtaining integral information characterizing the averaged biochemical processes, in fact, over the entire life of the animal [25].

Data on the concentration of chemical elements in various organs and tissues of animals can become the basis for the development of methods for improving production indicators, optimizing the use of resources and obtaining economically profitable, high-value food products [26]. The study of the relationship between chemical elements in the body of healthy animals can be a starting point for further assessment of metabolic consequences in conditions of increasing pollution caused by anthropogenic influence [27]. There are works showing the dependence of the content of some chemical elements on others, for example, some parts of the feathers of laying hens can be markers of zinc levels in blood serum, muscles and bones $[28,29]$.

Phosphorus is one of the most researched macronutrients in pig nutrition, but there are a number of gaps in knowledge about it at the macroorganism level [30]. About $80-85 \%$ of phosphorus is in bone tissue in the form of hydroxyapatite, the remaining amount is in soft tissues, here it is the main intracellular anion, a component of ATP and ADP, nucleic acids, 
phospholipids. Phosphorus is associated with mitochondrial respiration and oxidative phosphorylation. Thus, the main function of phosphorus is the structural and metabolic support of mammalian growth [31]. The main stages of macronutrient homeostasis in the body are its absorption in the small intestine, absorption and excretion in the kidneys, deposition in bone tissue. The leading regulators of this process are endocrine factors, there is also a genetic component [32]. The main consequences of an excess or deficiency of this chemical element in pigs are rickets and osteomalacia [33].

The quality and safety of agricultural products is affected by the health status of animals and the ecological environment of their habitat, therefore, systematic monitoring of the chemical composition of the animal body and its other parameters is necessary [34]. There is also an opinion that it is impossible to achieve, for example, complete individual elimination of micronutrient deficiency, since a general strategy with several types of impact is needed, taking into account the characteristics of specific regions, vegetation, prevailing sectors of agriculture [35]. Consequently, science faces a large-scale and complex task against the background of a shortage of fully satisfying food products, where elementology is an integral part.

The aim of the study was to establish links between the level of phosphorus and macro- and microelements in the bristles of Landrace pigs.

\section{Materials and methods}

The study was carried out on large pig-breeding farm in the Altai Territory in 2016-2020. on a group of clinically healthy 6-month-old pigs of the Landrace breed. The conditions for keeping animals were standard [36]. The pigs were vaccinated according to the plan of veterinary and preventive measures of the farm. During fattening, the animals were subjected to elements of general and special research by veterinary specialists. Feeding the pigs was typical with the use of complete compound feed, the amount of which increased during growth in accordance with the norms and recommendations. Nutritional, mineral and vitamin content has been balanced. Control of compound feed was carried out in accordance with the nomenclature of guaranteed and additional indicators in accordance with GOST [37, 38]. Water for drinking animals came from farm self-supply source, its quality corresponded to the second class of GOST [39].

The bristles of pigs were examined. Hair samples were cut with ethanol-purified stainless-steel scissors from the dorsal neck. The number of samples was 15. A sample of bristles weighing $100 \mathrm{mg}$ was carried out using bidistilled water, acetone and deionized water sequentially according to the scheme. Sample preparation included dissolution in nitric acid at high autoclave temperatures. Elemental analysis was performed by inductively coupled plasma atomic emission spectrometry on an iCAP-6500 spectrometer from Thermo Scientific (USA) [40].

The obtained values were processed using the Statistica 8 software (StatSoft Inc., USA). The distribution pattern was assessed using the Shapiro-Wilk test. The Pearson correlation coefficients (r) are calculated.

The reported study was funded by RFBR according to the research project № 20-31690029.

\section{Results and discussion}

The level of phosphorus in the bristles of Landrace pigs is associated with medium, high and very high positive bonds, both with individual macronutrients and microelements (Table 1). 
Table 1. The relationship of phosphorus levels with macro- and microelements in the bristles of Landrace pigs.

\begin{tabular}{|c|c|c|c|}
\hline Correlated parameters & $\mathrm{n}$ & $\mathrm{r} \pm \mathrm{Sr}$ & $\mathrm{P}$ \\
\hline $\mathrm{P}-\mathrm{Mg}$ & 15 & $0.749 \pm 0.184$ & $>0.99$ \\
\hline $\mathrm{P}-\mathrm{Ca}$ & 15 & $0.645 \pm 0.212$ & $>0.99$ \\
\hline $\mathrm{P}-\mathrm{Mn}$ & 15 & $0.968 \pm 0.070$ & $>0.999$ \\
\hline $\mathrm{P}-\mathrm{Cu}$ & 15 & $0.823 \pm 0.158$ & $>0.999$ \\
\hline $\mathrm{P}-\mathrm{Fe}$ & 13 & $0.662 \pm 0.225$ & $>0.95$ \\
\hline $\mathrm{P}-\mathrm{Sr}$ & 15 & $0.895 \pm 0.124$ & $>0.999$ \\
\hline
\end{tabular}

Phosphorus and magnesium in a macroorganism have significant biochemical points of contact, for example, these are intracellular components with the main place of accumulation in bone tissue in the form of the same organic component, they also have an important structural and synthetic role in the production of ATP molecules [41]. Phosphorus, magnesium and calcium have a common mechanism that governs their metabolism and maintenance of homeostasis, it is controlled by parathyroid hormone, calcitonin and calcitriol, which provide mobilization, accumulation, release and reabsorption of these ions in target organs [42]. Our data indicate the presence of high and medium strength bonds between the pairs of these macronutrients, that is, they are also conjointly «preserved» in the considered derivative of the skin of pigs.

With regard to trace elements, a direct connection of a very high strength between phosphorus and manganese has been explained, possibly due to the fact that manganese affects the exchange of phosphorus and calcium, referring to the calcium group of chemical elements [43]. Manganese and copper are micronutrients regulatory for bone growth and development, for example, demonstrating, like phosphorus, associated positive associations with the morphological properties of individual bone structures, such as weight, length and volume [44]. Direct references indicating a directly proportional relationship between phosphorus and iron have not been found, but there is evidence that pigs that received iron nanopowder increased the level of a macronutrient in the blood, it has been suggested that the relationship is synergistic [45]. We have established an even stronger positive relationship between phosphorus and strontium than between phosphorus and calcium, strontium is similar in properties to calcium and is able to replace it in hydroxyapatite, leading to the destruction of bone tissue [46].

For a further more detailed assessment of the phenofond of the Landrace pigs, possible connections between microelements, which correlated with phosphorus, were assessed (Table 2).

Table 2. Correlations of macro- and microelements associated with the level of phosphorus in the bristles of pigs.

\begin{tabular}{|c|c|c|c|}
\hline Correlated parameters & $\mathrm{n}$ & $\mathrm{r} \pm \mathrm{Sr}$ & $\mathrm{P}$ \\
\hline $\mathrm{Mn}-\mathrm{Sr}$ & 15 & $0.918 \pm 0.110$ & $>0.999$ \\
\hline $\mathrm{Mn}-\mathrm{Mg}$ & 15 & $0.843 \pm 0.149$ & $>0.999$ \\
\hline $\mathrm{Mn}-\mathrm{Cu}$ & 15 & $0.833 \pm 0.153$ & $>0.999$ \\
\hline $\mathrm{Mg}-\mathrm{Sr}$ & 15 & $0.879 \pm 0.132$ & $>0.999$ \\
\hline $\mathrm{Mg}-\mathrm{Cu}$ & 15 & $0.810 \pm 0.163$ & $>0.999$ \\
\hline $\mathrm{Ca}-\mathrm{Sr}$ & 15 & $0.660 \pm 0.208$ & $>0.99$ \\
\hline $\mathrm{Ca}-\mathrm{Cu}$ & 15 & $0.666 \pm 0.207$ & $>0.99$ \\
\hline $\mathrm{Ca}-\mathrm{Mn}$ & 15 & $0.659 \pm 0.209$ & $>0.99$ \\
\hline $\mathrm{Fe}-\mathrm{Sr}$ & 13 & $0.653 \pm 0.228$ & $>0.95$ \\
\hline $\mathrm{Fe}-\mathrm{Mn}$ & 13 & $0.756 \pm 0.197$ & $>0.99$ \\
\hline $\mathrm{Fe}-\mathrm{Mg}$ & 13 & $0.615 \pm 0.238$ & $>0.95$ \\
\hline
\end{tabular}


A calcium group of chemical elements is allocated, among which positive connections of different strengths are established between themselves and other microelements. In pairs, among manganese, strontium, magnesium and calcium, high, very high, and medium correlation coefficients are recorded, possibly, as indicated above, this is due to the coordinating function of the former in relation to bone tissue and the structural participation of magnesium, strontium and calcium. It should be noted against this background that there is a direct connection between magnesium and strontium and a pair of calcium - strontium. Manganese and copper also have a high bond, which can be explained by the generality of their effect on hematopoiesis [47, 48]. It was shown that the introduction of additional amounts of magnesium into the body of rats led to an increase in the level of copper and iron in certain organs and tissues [49], in our case, a high and medium positive relationship was established between chemical elements at the level of tissue depot. It is also known that the exchange of calcium and copper are closely related, for example, the optimal intake of copper in the body of sheep leads to a positive balance of the macronutrient and better absolute and relative retention. Also in the literature, it has already been mentioned about positive connections between iron and manganese only in the internal organs of cattle [50]. The exchange of chemical elements was given great attention by scientists around the world, but it is still relevant to study the chemical status of the organism of farm animals as part of a comprehensive assessment of the phenofonds of various species and breeds, which is caused by insufficient data on the distribution, redistribution of macro- and microelements, and the interaction between them at the level macroorganism in normal and pathological conditions.

\section{Conclusions}

In the bristles of Landrace pigs, positive correlations of varying strength, characteristic of healthy animals, have been established between phosphorus and the calcium group of chemical elements (calcium, magnesium, manganese), copper, strontium, and iron.

Numerous positive relationships have been revealed between macro- and microelements associated with the level of phosphorus in the bristles.

All the established correlations in the bristle, as the final link in the exchange of chemical elements, are consistent with the literature data, highlighting their relationship in organs and tissues.

\section{References}

1. L.M. Tsoi, Journal of VNIIMZH, 1(29), 123-126 (2018)

2. O.V. Kostenko, Agricultural Science Euro-North-East, 20(3), 290-297 (2019)

3. I.A. Minakov, V.A. Kuvshinov, Sciense and education, 4(1) (2021)

4. K.S. Akimova, T.N. Gagloeva, Sciense and education, 2(2) (2019)

5. J. M. Higuera, A. B. S. Silva, W. Henrique, S. N. Esteves, W. Barioni Jr, G. L. Donati, A. R. A. Nogueira, Biological Trace Element Research (2021)

6. J. Novoselec, Ž. Klir, M. Domaćinović, Z. Lončarić, Z. Antunović, Poljoprivreda, 24(1), 25-34 (2018)

7. D. Cannas, E. Loi, M. Serra, D. Firinu, P. Valera, P. Zavattari, Nutrients, 12(7), 2074 (2020)

8. O.A. Zaiko, Variability and correlation of chemical elements in organs and tissues of pigs of early maturing meat breed SM-1, 183 (Novosibirsk, 2014) 
9. M.V. Strizhkova, Content, variability and correlation of macroelements in organs and tissues of black-and-white cattle, 126 (Novosibirsk, 2018)

10. K.N. Naroznykh, Variability, correlations and the level of heavy metals in organs and tissues of Hereford cattle in the conditions of Western Siberia, 163 (Novosibirsk, 2019)

11. C. N. Amadi, C. Frazzoli, O. E. Orisakwe, Journal of Environmental Science and Health, 38(1), 21-60 (2020)

12. E.A. Lukina, A.V. Ledina, S.I. Rogovskaya, Russian Journal of Woman and Child Health, 3(4), 248-253 (2020)

13. C. T. Clark, L. Horstmann, N. Misarti, Science of the Total Environment, 772, 145500 (2021)

14. M. A. Qayyum, M. H. Shah, Scientific Reports, 9(1), 15363 (2019)

15. K. R. Wessells, K. H. Brown, C. D. Arnold, M. A. Barffour, G.-M. Hinnouho, D.W. Killilea, S. Kounnavong, S.Y. Hess, Biological Trace Element Research, 199(2), 442-452 (2021)

16. A.V. Nazarenko, O.A. Zaiko, T.V. Konovalova, O.I. Sebezhko, M.V. Strizhkova, O.S. Korotkevich, K.N. Narozhnykh, V.L. Petukhov, V.A. Andreeva, Trace Elements and Electrolytes, 38(3), 150 (2021)

17. K.N. Narozhnykh, T.V. Konovalova, I.S. Miller, M.V. Strizhkova, O.A. Zaiko, A.V. Nazarenko. Fundamental Research, 26(2), 5815-5819 (2015)

18. T.V. Konovalova, K.N. Narozhnykh, V.L. Petukhov, Y.I. Fedyaev, N.I. Shishin, O.I. Sebezhko, O.S. Korotkevich, E.V. Kamaldinov, L.V. Osadchuk, Journal of Trace Elements in Medicine and Biology, 44(S), 74 (2017)

19. T. Bechshofta, Y. Luob, A. M. Boharta, A. E. Derochera, E. S. Richardsonc, N. J. Lunnd, D. G. Pearson, Ecological Indicators, 119, 106822 (2020)

20. S.A. Miroshnikov, A.V. Skalny, O.A. Zavyalov, A.N. Frolov, A.R. Grabeklis, Biological Trace Element Research, 194(1), 145-151 (2019)

21. B.L. Panov, V.L. Petukhov, L.K. Ernst, I.I. Gudilin, S.G. Kulikova, O.S. Korotkevich, V.N. Dementyev, N.N. Kochnev, V.G. Marenkov, M.L. Kochneva, Problems of Farm Animal Breeding, 283 (1997)

22. International Zinc Nutrition Consultative Group (2018) Assessing population zinc exposure with hair or nail zinc. IZiNCG Technical Brief No. 8. Available online: www.izincg.org (accessed 9 July 2019)

23. A.V. Harlamov, A.N. Frolov, O.A. Zavyalov, A.M. Miroshnikov, Beef cattle bulletin, 4(87), 53-58 (2014)

24. S.F. Tyutikov, V.V. Ermakov, Method for the diagnosis of chronic microelementosis of agricultural ungulates, Patent for invention RU 2477483 C1, 10.03.2013. Application No. 2012107116/15 dated February 28, 2012.

25. V.V. Salautin, S.E. Salautina, Scientific Notes of the Kazan State Academy of Veterinary Medicine. N.E. Bauman, 223(3), 157-160 (2015)

26. D. M. Ribeiro, M. P. Mourato, A. M. Almeida, Tropical Animal Health and Production, 51(5), 1019-1032 (2019)

27. V.L. Petukhov, E.S. Kleptsyna, A.I. Zheltikov, I.V. Petukhov, O.S. Korotkevich, V.S. Tokarev, Method for assessing zinc accumulation in muscles and bones of a bird, invention RU 2264094 C2, 20.11.2005. Application No. 2001118648/13 dated 05.07.2001. 
28. M. M. Misiura, J. A. N. Filipe, C. L. Walk, I. Kyriazakis, British Journal of Nutrition, 124(3), 256-272 (2020)

29. E. Pavlov, R. Aschar-Sobbi, M. Campanella, R.J. Turner, M.R. Gomez-Garcia, A.Y. Abramov, Journal of Biological Chemistry, 285(13), 9420-9428 (2010)

30. S.T. Anderson, L.J. Kidd, M.A. Benvenutti, M.T. Fletcher, R.M. Dixon, Animal Production Science, 57(11), 2291-2303 (2017)

31. T. Berndt, R. Kumar, Physiology, 24, 17-25 (2009)

32. E. Georgiadou, H. Marketou, G. Trovas, I. Dontas, N. Papaioannou, K. Makris, A. Galanos, A. G. Papavassiliou, In Vivo, 31(1), 145-150 (2017)

33. H. Reyer, M. Oster, D. Wittenburg, E. Murani, S. Ponsuksili, K. Wimmers, Frontiers in Genetics, 10, 590 (2019)

34. K. Bühler, A. Liesegang, B. Bucher, C. Wenk, J. Broz, Journal of Animal Science, 88, 3363-3371 (2010)

35. O.I. Sebezhko, O.S. Korotkevich, T.V. Konovalova, I.K. Biryulya, V.L. Petukhov, E.V. Kamaldinov, K.N. Narozhnykh, L.V. Osadchuk, 3rd International Symposium for Agriculture and Food, 100 (2017)

36. GOST 28839-2017. Agricultural animals. Pigs. Zootechnical requirements for keeping for fattening. - Instead of GOST 28839-90; entered 2018-07-01, 4 (M.: Standartinform, 2017)

37. GOST R 51550-2000. Compound feed concentrates for pigs. General technical conditions. - Introduced for the first time; entered 2001-01-01, 10 (Moscow: IPK Standards Publishing House, 2002)

38. GOST R 51850-2001. Compound feed products. Acceptance rules. Packaging, transportation and storage. - Introduced for the first time; entered 2004-01-01, 4 (Moscow: IPK Standards Publishing House, 2002)

39. GOST 2761-84. Sources of centralized drinking water supply. Hygienic, technical requirements and selection rules (with Amendment No. 1) - Instead of GOST 17.1.3.03-77; entered 1986-01-01, 12 (M.: Standartinform, 2006)

40. A.R. Tsygankova, A.V. Kuptsov, A.I. Saprykin, K.N. Narozhnykh, T.V. Konovalova, O.I. Sebezhko, O.S. Korotkevich, V.L. Petukhov, L.V. Osadchuk, Journal of Pharmaceutical Sciences and Research, 9(5), 601-605 (2017)

41. I.V. Tereshchenko, Clinical medicine, 86(7), 47-51 (2008)

42. V.S.Luk'yanchikov, New research, 2(31), 5-13 (2012)

43. S.V. Butusova, E. Yu. Neronova, Recent trends in science and education, 73-76 (2017)

44. M.R. Tatara, I. Luszczewska-Sierakowska, W. Krupski, Biological Trace Element Research, 185(1), 98-105 (2018)

45. V.V. Kulakov, Influence of ultrafine iron powder on physiological parameters, pig productivity and quality of slaughter products, dissertation for the degree of candidate of biological sciences, 145 (Ryazan, 2011)

46. N. Synhaeve, N.M. Wade-Gueye, S. Musilli, J. Stefani, L. Grandcolas, G. Gruel, M. Souidi, I. Dublineau, J.M. Bertho, Journal of Applied Toxicology, 34(1), 76-86 (2014)

47. Z.W. Myint, T.H. Oo, K.Z. Thein, A.M. Tun, H. Saeed, Annals of Hematology, 97(9), 1527-1534 (2018)

48. S.A. Nedovesova, A.V. Anoshin, A.P. Kozlova, R.I. Aizman, Russian Journal of Physiology. THEM. Sechenov, 105(8), 1021-1030 (2019) 
49. V.S. Zoteev, D.B. Mandzhiev, D.Sh. Gayirbegov, G.A. Simonov, Sheep, goats, woolen business, 2, 31-34 (2018)

50. K.N. Narozhnykh, N.V. Efanova, O.S. Korotkevich, V.L. Petukhov, Dairy and beef cattle breeding, 1, 24-25 (2013) 